\title{
Warrant of Termination of Investigation (SP3) Issued Based on Peace Agreement Between Suspects and Reporters in Ordinary Offences
}

\author{
Azizul Hakiki \\ Airlangga University, Indonesia \\ azizulhakiki@gmail.com
}

\begin{abstract}
Warrant of Termination of Investigation (SP3 - Surat Perintah Penghentian Penyidikan) is applied as the power granted to the investigator of a criminal act. Article 109 paragraph (2) of Law No. 8 of 1981 on the Criminal Procedure Code (KUHAP - Kitab Undang-Undang Hukum Acara Pidana) states that there are three requirements to stop a criminal investigation: (a) insufficient evidence; (b) the act committed by the suspect is not a criminal offence; and (c) the investigation is stopped by law. These three conditions are alternative conditions. At the implementation level, there are many cases that are terminated because they fulfill these three requirements. However, it is not uncommon for cases that have progressed to the stage of investigation be stopped as well because the suspected and the reporter reached a peace agreement through mediation facilitated by police investigators. Whereas, in this context, the status of this case is an ordinary offence status which means that the revocation of the report has no consequences with the ongoing investigation. Peace agreements impact ongoing investigations. Whereas the investigation should be stopped and police should revoke the offense report, under extant legislation, investigations maintain ordinary offence status, meaning revocation of the offense report has no effect on the ongoing investigation. The investigation cannot be stopped with any other reasons excepts those that stated in Article 109 paragraph (2). The fact that the revocation of the report of investigation leads to the termination of the ongoing investigation as evidenced by the issuance of SP3. While issuance of SP3 enables termination of an ongoing investigation by revoking the report of investigation, investigation termination requirements explicitly state that an agreement reached through a mediation mechanism cannot provide legal grounds to issue SP3. Investigations that terminated based on an agreement achieved by mediation mechanism will create space for third parties to utilize a pre-trial mechanism whose purpose is to test the validity or termination of the investigation.
\end{abstract}

KEYWORDS: Termination of Investigation, Criminal Law, Criminal Procedure.

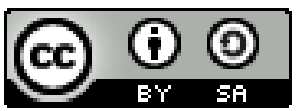

Copyright $\odot 2019$ by Author(s)

This work is licensed under a Creative Commons Attribution-ShareAlike 4.0

International License. All writings published in this journal are personal views of the authors and do not represent the views of this journal and the author's affiliated institutions.

\section{HOW TO CITE:}

Hakiki, Azizul. "Warrant of Termination of Investigation(SP3) Issued Based on Peace Agreement Between Suspects and Reporters in Ordinary Offenses" (2019) 6:2 Lentera Hukum 279-288.

Submitted: April 28, 2019 Revised: May 13, 2019 Accepted: May 27, 2019 


\section{INTRODUCTION}

A criminal act can be classified into a heavy and light categories, in terms of the severity and severity of the criminal threat. Criminal act according to Moeljatno, as quoted by Eddy O.S Hiariej, is an act that is legally prohibited and threatened with criminal offenses, committed by anyone who violates the prohibition. ${ }^{1}$ A large number of criminals greatly influence the number of cases handled and investigated by the Indonesian Police, ranging from cases with heavy categories to light categories. All cases must be processed to arrive at a decision on the case, such that rule of law can be maintained. A criminal act processed by an investigator not only upholds the rule of law, but also creates human rights protections for victims and society in general. The public will feel safe and as though their human rights are protected if and when criminal offenders are legally processed due to criminal acts that they have violated. According to Widodo Ekatjahjana, a constitutional law analyst, human rights are basic rights that are natural and inherent in every human being, therefore the state must respect and protect. ${ }^{2}$

At the level of implementation, there is often a case that is stopped by the investigator because it fulfills the requirements for cessation set forth by Article 109 paragraph (2) of the Criminal Procedure Code, namely insufficient evidence, noncriminal behavior, or legislation providing grounds for cessation. As a result of any of these three conditions, the case must be stopped and will not proceed to the court. Reconciliation or peace agreements between suspects and reporting parties is often achieved at the investigation level, which similarly results in the police report being revoked and cessation of the case, though the case is not necessarily a case that is classified as a petitioned offence. ${ }^{3}$ To establish legality of case termination in the investigation stage, investigators must issue a warrant for the termination of the investigation. Investigators often use the pretext of discretion to provide a basis for arguments in support of terminating investigations as a result of peace agreements between the suspect and the reporter, regardless of whether the termination of the case belongs to the category of petitioned offence or ordinary offence. In the context of administrative law, applied discretion must meet the rules set by administrative law, meaning that it cannot be arbitrarily sheltered behind the word "discretion" itself.

In the context of petitioned offences, there is an option to withdraw complaints, resulting in the cessation of handling a case; however, in the context of ordinary offences there is no such option. Even if a peace agreement is reached between the suspect and the reporter, resulting in the withdrawal of the report or complaint, it does not have any effect on the handling of the case. Based on the description above, this

1 Eddy O.S Hiariej, Prinsip-Prinsip Hukum Pidana : Edisi Revisi (Yogyakarta : Cahaya Atma Pustaka, 2016) at 121 .

2 Widodo Ekatjahjana, Negara Hukum, Konstitusi, dan Demokrasi (Jember : Jember University Press, 2015) at 62 .

3 According to Adami Chazawi, complaint offense is a form of criminal acts for which criminal prosecution can be required to make a complaint in advance by the person who has the right to file a complaint, namely the victim. Adami Chazawi, Pelajaran Hukum Pidana Bagian I (Jakarta: Raja Grafindo, 2014) at 132. 
paper intends to discuss the validity of issuing a Warrant of Termination of Investigation by investigators based on reconciliation or peace agreement achieved between suspects and reporting parties in ordinary offences.

\section{THE INVESTIGATION AND TERMINATION OF THE INVESTIGATION}

The investigations carried out by Indonesian Police investigators are very closely related to the authority given to them. Authority is the legitimacy of someone carrying out an action within the corridor of government officials or state organs. In the context of Indonesian Administrative Law, authority is a core concept because it has a very important position, as stated by F.A.M Stroink and J.G Steenbeek. ${ }^{4}$ There are three sources of authority: the attribution of authority, the authority of delegation, and the authority of mandate. H.D van Wijk and Willem Konijnenbelt gave a definition of the three as quoted by Ridwan HR. First, attribution is the granting of government authority by legislators to government organs. ${ }^{5}$ Second, delegation is the delegation of government authority from one government organ to another. ${ }^{6}$ Third, mandate occurs when an organ of government allows its authority to be used by other organs in its name. ${ }^{7}$ Based on the description above, it is clear that authority obtained by attribution is the original authority obtained from legislators. In other words, the organ of government obtains authority directly from certain articles in statutory regulation. ${ }^{8}$

The Indonesian Police carries out the functions of the state government in the areas of security maintenance, law enforcement, protection, and service to the public. ${ }^{9}$ The purpose of government, based on the provisions of Article 1 No. 2 of Law No. 30 of $2014^{10}$ concerning Government Administration, is to carry out administrative functions which include regulation, service, development, empowerment, and protection. The Indonesian Police have delegated authority in matters of protection, security, and public order. The implication is that the Indonesian Police is part of a government body that is directly responsible to the President. Therefore, it must be understood that the duties and authority of the Indonesian Police are part of the government's duties in the field of law enforcement.

In order to carry out the functions of government, authority given to the police by law is that of carrying out investigations as stipulated in the Criminal Procedure Code. ${ }^{11}$ An investigation is a series of investigator actions in terms of and according to the method stipulated in the Criminal Procedure Code to search for and collect evidence in order to find the suspect, as stated at the provisions of Article 1 No. 2 of the Criminal

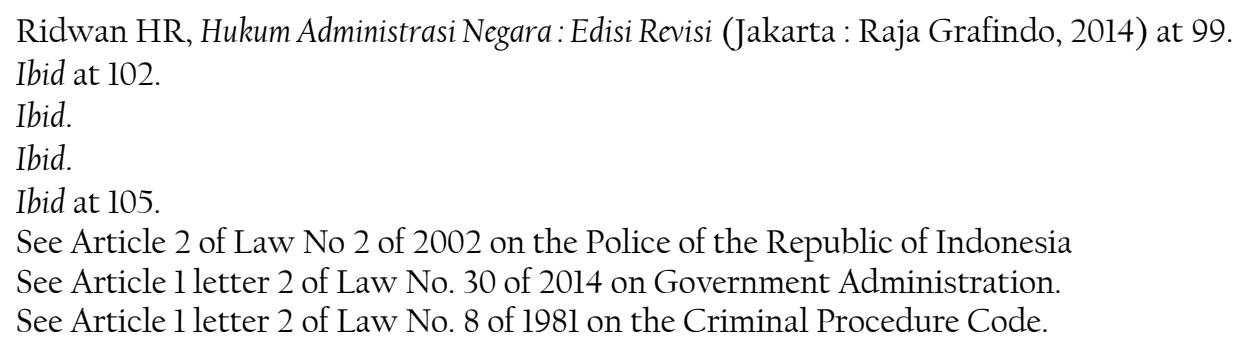


Procedure Code. The result of the investigation process is the identification of an individual who is suspected of being a criminal offender based on two pieces evidence supporting his agency. This argument arises based on a careful understanding of the provisions of Article 1 No. 2 of the Criminal Procedure Code, especially in the sentence "searching for and gathering evidence that occurs to find the suspect." It can be concluded that investigation is not intended to determine whether the case involves a criminal act or not, but rather it is aimed at finding and gathering evidence to identify the criminal offender. ${ }^{12}$

When the investigator carries out an investigation,they are burdened with an obligation, namely sending a Notice of Commencement of Investigation (SPDP) to the Public Prosecutor who in this case is the sole authority in the case of prosecution (Dominus Litis). The content of SPDP should explain that the investigation has begun. This activity is meant as a check between the authorities of investigation and prosecution. Based on the provisions of Article 1 No. 2 of the Criminal Procedure Code as stated above, authorities are able to legitimate the actions of investigators, which are identified in Article 7 of the Criminal Procedure Code ${ }^{13}$ and explained as follows:

1. Carry out inspection measures

a. Calling witnesses and/or suspects

b. Notify the suspect of their right to be accompanied by a lawyer / legal counsel c. Information by witnesses and/or suspects is free and not under oath

2. Make the necessary forced effort
a. Arrest
b. Detention
c. Foreclosure
d. Search

Didik Endro Purwoleksono believes that the summons listed as l(A) above are included in forced efforts, even though they are not listed as forced efforts referred to by the Criminal Procedure Code. Reasons that reinforce this opinion are: (i) someone who is called becomes a witness to attend, both in front of the investigator during the investigation process and in the trial process, and is required to fulfil the call; (ii) if the witness does not want to attend, they can be forced to attend; (iii) absence of a witness without a valid reason is threatened with criminality. ${ }^{14}$

3. Assign a suspect

Determination of suspects is the result of the investigation process. The function of the investigation process is to collect evidence and to find out who the suspect is, such that a criminal act becomes clear. At least two pieces of evidence as required by Article 184 paragraph (1) of the Criminal Procedure

12 Tholib Effendi, Dasar-Dasar Hukum Acara Pidana: Perkembangan dan Pembaharuannya di Indonesia (Malang : Setara Press, 2015) at 82.

13 See Article 7 of Law No. 8 of 1981 on the Criminal Procedure Code.

14 Didik Endro Purwoleksono, Hukum Acara Pidana (Surabaya : Airlangga University Press, 2015) at 80. 
Code $^{15}$ must be discovered first, before deciding to assign someone as a suspect. Before a person is named a suspect, they must first be examined as a witness or "potential suspect." This requirement is stipulated by the Decision of the Indonesian Constitutional Court No. 21 / PUU-XII / 2014.

\section{Case Reconstruction ${ }^{16}$}

In the Chief of Police Regulation (Perkap) No. 14 of 2012, the mechanism of case reconstruction is known as part of police investigation management, which in turn is part of monitoring and controlling investigative activities. Case reconstruction is divided into two types: (1) reconstruction of an ordinary case and (2) reconstruction of a special case. Case reconstruction is usually done to address certain matters related to investigation strategy at the beginning, middle, and end of the investigation process.

The whole series of investigative processes carried out by investigators will be summarized in an official report referred to as the Police Investigation Report (BAP), which is put together with the case file. The files are then submitted to the prosecutor's investigator at the attorney's office, who will examine the file's completeness. If the prosecutor states that the file is not complete, it will be returned to the investigator along with instructions to be completed. If the prosecutor states that the file is complete, then the investigator hands over responsibility for the suspect and evidence to the prosecutor's office. After responsibility for the suspect and evidence have been transferred, the investigation has been legally completed and all responsibility is transferred to the prosecutor's office, which must immediately appoint a public prosecutor for the case.

When the process of gathering evidence is ongoing, it sometimes leads to the discovery that an act initially suspected of being criminal is not criminal at all. Or the act is criminal, yet there is not enough evidence to bring a suspect to the trial process in court. Similarly, investigators may discover facts indicating that the investigation must be stopped by law because there are factors that abort the authority to prosecute the criminal as stipulated in the articles in chapter VIII of the Criminal Code. ${ }^{17}$ In any of the aforementioned incidents, the investigation must be stopped based on the provisions of Article 109 paragraph (2) of the Criminal Procedure Code, which reads as follows:

"In the event that the investigator stops the investigation because there is not enough evidence or the incident turns out to not be a criminal offence or the investigation is stopped by law, the investigator notifies the prosecutor, suspect or his family."

M. Yahya Harahap stated that the rationale of giving authority to stop investigations is as follows. First, this is aimed to uphold the principle of quick, simple, and low-cost justice, and at the same time to enforce the rule of law in people's lives. If

\footnotetext{
15 Evidence as outlined in Article 184 (1) of Law No. 8 of 1981 on Criminal Procedure Code comprises: witness testimony, expert testimony, letter, guidance, and defendant's testimony.

16 Aristo M.A Pangaribuan, Arsa Mufti, Ichsan Zikry, Pengantar Hukum Acara Pidana di Indonesia (Jakarta: Raja Grafindo, 2017) at 63.

17 See Law No. 8 of 1981 on the Criminal Procedure Code.
} 
the investigator concludes that based on the results of the investigation there is insufficient evidence or reason to sue the suspect/defendant at the trial, it is better for the investigator to officially declare the investigation void and immediately create legal certainty for the investigation, especially the suspect and the public. Second, it is to avoid demands for compensation, because if the case is continued but there is insufficient evidence or reason to sue, it automatically entitles the suspect/defendant to demand compensation based on Article 95 of the Criminal Procedure Code. ${ }^{18}$

The consequence of discontinuing the investigation is that the investigator must provide a sign that has a legitimate function: termination of the investigation. In the implementation level, if the examination of a criminal case is stopped at the stage of the investigation, the investigator issues a letter called SP3. With the issuance of this letter, the investigation process of the criminal case will automatically end. The order to terminate the investigation has no authentic definition in the legislation, but instead is related to the format of the letter explained in the Attorney General's Decree No. KEP518/A/JA/11/2001 concerning Amendment to the Attorney General's Decree No. KEP132/A/JA/11/1994.

\section{THE VALIDITY AND ISSUANCE IMPLICATION OF SP3 ON THE BASIS OF PEACE AGREEMENTS BETWEEN SUSPECTS AND REPORTERS}

Criminal cases that are being processed at the stage of investigation have two possibilities. They can either continue to the trial stage in court, or stop at the investigation stage itself. If the case stops at the stage of the investigation, then there should be reasons for the termination of a case, as described in the previous discussion. To establish legitimacy for the termination of a criminal case investigation, the investigator issues a letter called the Warrant of Termination of Investigation (SP3).

Problems arise when the investigation process reaches a peace agreement between the suspect and the reporter, which results in the withdrawal of the police report by the reporter, even though the reported criminal acts are included in the category of non-petitioned offences or ordinary offences. The implication of the revocation of the police report is that the investigator decides not to continue the investigation of the case, which is then legalized by the issuance of the Warrant of Termination of Investigation (SP3). Whereas when referring to Article 109 paragraph (2) of the Criminal Procedure Code as described in the previous discussion, the achievement of a peace agreement between the suspect and the reporter and also the revocation of the police report in the case of ordinary offences is not a condition for a criminal case investigation to be stopped. The conditions for obtaining an investigation into a criminal case are limited to those stipulated in Article 109 paragraph (2) of the Criminal Procedure Code, also adopted in the Regulation of the Chief of Police (Perkap) No. 14 of 2012 concerning Management of Criminal Acts Investigation Article 76

18 M. Yahya Harahap, Pembahasan Permasalahan dan Penerapan KUHAP: Penyidikan dan Penuntutan (Jakarta: Sinar Grafika, 2012) at 150. 
paragraph (1). This means that the conditions are very strong, to the extent that they must be arranged into two different legal products.

In the event of investigation termination based on a peace agreement between the suspect and the reporter and revocation of the police report by the reporter, it seems difficult to take refuge behind the word discretion. Discretion or in the context of Indonesian Administration Law is referred to as Freies Ermessen or Discretionary Power, according to Nana Saputra as quoted by Ridwan HR, is freedom given to administrative tools, namely freedom which basically allows state administration tools to prioritize the effectiveness of achieving a goal rather than sticking to rule of law. ${ }^{19}$ Article 1 No. 9 of Act No. 30 of 2014 concerning Government Administration provides the definition of discretion as follows:

"Discretion is a decision and/or action determined and/or carried out by

Government Officials to overcome the concrete problems faced in the administration of government in terms of regulations that provide choices, fails to regulate, is incomplete or unclear, or involves government stagnation."

Laica Marzuki, as quoted by Ridwan HR, states that Freies Ermessen is the freedom given to the state administration in the framework of government administration, in line with the increasing demands of public services that must be given by the state, towards the increasingly complex socio-economic life of citizens. ${ }^{20}$ Furthermore, Sjachran Basah, also quoted by Ridwan HR, explains the elements of Freies Ermessen in the context of the rule of law state, as follows: ${ }^{21}$ (a) aimed at carrying out public service tasks; (b) an active action from the state administration; (c) made possible by law; (d) taken on its own initiative; and (e) intended to solve important problems that arise suddenly.

If we look at the description of Freies Ermessen in the paragraph above, it is expressly stated that discretion must be an action made possible by law. Termination of investigation based on a peace agreement between the suspect and the reporter in the case of ordinary offences is clearly not included in the act of discretion. The requirements of terminating the investigation have been set limitedly in Article 109 paragraph (2) of the Criminal Procedure Code and reaffirmed in Article 76 paragraph (1) Regulation of the Chief of Police (Perkap) No. 14 of 2012 concerning Management of Criminal Investigation, neither of which state that a peace agreement between suspect and reporter followed by revocation of the report in the ordinary offence is a condition for the termination of the investigation. In the end it can be stated explicitly that termination of investigation based on peace between the suspect and the reporter in terms of ordinary offences is clearly not included in the definition of a "discretionary act" because it is, in this case, contrary to the Criminal Procedure Code and the Chief of Police Regulation (Perkap). Termination of investigation that is not in accordance with applicable laws also has implications for the Warrant of Termination of Investigation

19 Ridwan HR, supra note 5 at 170.

20 Ibid at 171.

21 Ibi at 170 . 
(SP3) issued. As a result, it is not excessive if it is said that the Warrant of Termination of Investigation (SP3) issued based on a peace agreement between the suspect and the reporter and followed by revocation of a police report by the reporter is an illegal SP3. By declaring the invalidity of the Warrant of Termination of Investigation (SP3) issued as described above, we must ask what efforts can be taken to cancel the issued Warrant of Termination of Investigation (SP3). Pre-trial mechanisms can considered a solution to this problem. Pre-trial is an institution authorized by the Criminal Procedure Code to guarantee and provide protection for human rights of suspects, families of suspects, and involved third parties.

Pre-trial institutions are born because there is no institution that oversees and assesses forced efforts to guarantee human rights in the HIR. Pre-trial in principle aims to carry out horizontal oversight of all acts of forced effort by law enforcement officers in the interest of criminal act investigation so that these actions do not actually conflict with applicable law, in addition to internal supervision within the apparatus itself. ${ }^{22}$ Pre-trial is not a separate institution but is limited to the granting of new authority by the Criminal Procedure Code to the District Court. Article 77 of the Criminal Procedure Code $^{23}$ regulates the authority of pre-trial institutions stated as follows:

"The District Court has the authority to examine and decide, in accordance with the provisions stipulated in this law about:

a. the legality of the arrest, detention, termination of investigation or termination of prosecution;

b. compensation and/or rehabilitation for a person whose criminal case is stopped at the level of investigation or prosecution."

However, in its development, the authority of the pre-trial institution was added, in order to test the validity of the determination of the suspect. This refers to the decision of the Republic of Indonesia Constitutional Court No. 21 / PUU-XII / 2014.

Based on the above description, the Warrant of Termination of Investigation (SP3) issued due to the termination of investigation as the result of a peace agreement between the suspect and the reporter is followed by the revocation of the police report in the case of ordinary offences, can be submitted to the pre-trial institution by parties involved on the basis of law so that it is then tested and declared invalid.

\section{CONCLUSION}

The Police of the Republic of Indonesia is a state institution that has the function of manifesting state government in the areas of security maintenance, law enforcement, protection, and service to the public. Police authority was given by the law as a result of its function. Carrying out investigative actions is an implementation of the law enforcement function, as well as specific authority given to the Indonesian Police institution. Investigations are carried out to gather evidence proving the occurrence of a

\footnotetext{
22 Aristo M.A Pangaribuan, Arsa Mufti, Ichsan Zikry, supra note 17 at 143.

23 See Article 77 of Law No. 8 of 1981 on the Criminal Procedure Code.
} 
criminal act and identifying the suspect. The whole series of investigative processes carried out by investigators will be summarized in the official report referred to as the Police Investigation Report (BAP) which is put together with the case file. When the investigator is collecting evidence, they often discover that an act which was initially suspected of being a criminal act is not a criminal act, is a criminal act but lacks sufficient evidence, or that the investigation should be stopped as a result of specific conditions stipulated by chapter VIII of the Criminal Code. As a result, the criminal investigation must be stopped.

In practice, problems arise when the investigation process reaches a peace agreement between suspect and reporter, which results in the withdrawal of the police report by the reporter, even though the reported criminal acts are included in the category of non-petitioned offences or ordinary offences. In the context of ordinary offences, even if the report or complaint is revoked, it does not have any impact on the case handling process, except that the case is feasible to be stopped because it fulfils the requirements as stipulated in Article 109 paragraph (2) of the Criminal Procedure Code. In fact, the revocation of the police report resulted in the termination of the investigation of the case, which was later legalized by the issuance of the Warrant of Termination of Investigation (SP3), both in the petitioned offences and ordinary offences. The reason for applying discretion cannot be used as a protector in this

problem, considering that this is not in accordance with the rules of discretion or Freies Ermessen. There is no choice but to declare that the Warrant of Termination of Investigation (SP3) issued is invalid. As a consequence of being considered illegitimate, SP3 must be tested to an institution that has the authority to test and declare that SP3 is invalid, namely a pretrial institution.

\section{REFERENCES}

Chazawi, Adami. Pelajaran Hukum Pidana Bagian I (Jakarta: Raja Grafindo, 2014).

Diantha, I Made Pasek. Metodologi Penelitian Hukum Normatif dalam Justifikasi Teori Hukum (Jakarta: Prenada Media Grup, 2016).

Effendi, Tholib. Dasar-Dasar Hukum Acara Pidana: Perkembangan dan Pembaharuannya di Indonesia (Malang: Setara Press, 2015).

Ekatjahjana, Widodo. Negara Hukum, Konstitusi, dan Demokrasi (Jember: Jember University Press, 2015).

Harahap, M. Yahya. Pembahasan Permasalahan dan Penerapan KUHAP: Penyidikan dan Penuntutan, (Jakarta: Sinar Grafika, 2012).

Hiariej, Eddy O.S. Prinsip-Prinsip Hukum Pidana : Edisi Revisi (Yogyakarta: Cahaya Atma Pustaka, 2016).

HR, Ridwan. Hukum Administrasi Negara: Edisi Revisi (Jakarta: RajaGrafindo, 2014).

Pangaribuan, Aristo M.A, Arsa Mufti, Ichsan Zikry. Pengantar Hukum Acara Pidana di Indonesia (Jakarta: RajaGrafindo, 2017). 
288 | Warrant of Termination of Investigation (SP3) Issued Based on Peace Agreement Between Suspects and Reporters...

Purwoleksono, Didik Endro. Hukum Acara Pidana (Surabaya: Airlangga University Press, 2015). 